\title{
Growth Performance, Yield \& Return of Puntius sarana (Hamilton, 1822) from Dry Seasonal Water Bodies of Angul District, Odisha, India
}

\author{
Rashmi Prabha Mishra ${ }^{1^{*}}$, Navin Kumar ${ }^{2}$, Sudhir Kumar Das ${ }^{3}$, \\ Jyotiprabha Mishra $^{4}$ and Nihar Ranjan Sarangi ${ }^{5}$
}

${ }^{1}$ Krishi Vigyan Kendra, Angul, Odisha, 6371592591, India

${ }^{2}$ Agriculture Coordinator, District Agriculture Office, Samastipur, India

${ }^{3}$ Department of Fisheries Resource Management, WBUAFS, Kolkata, India

${ }^{4}$ Krishi Vigyan Kendra, Sambalpur, Odisha, India

${ }^{5}$ Adl. Veterinary Surgeon, Jamankira, Odisha, 9790941773, India

*Corresponding author

\section{A B S T R A C T}

\section{Keywords \\ Growth performance, Yield, Return, Puntius sarana}

\section{Article Info}

Accepted:

05 February 2020

Available Online:

10 March 2020
The study was carried out with an objective to assess the technology of enhancement of fish production by incorporating Minor Carp Sps. in Composite fish culture system. The experiment was conducted for ten months from June, 2018 to March, 2019 in nine earthen ponds of 0.3 ha ( 3 no. ponds), 0.4 ha ( 3 no. ponds) $\& 0.5$ ha ( 3 no. ponds) of three different villages of Angul district. In the first phase Pre-stocking pond preparation methods are followed i.e. removal of predatory and weed fishes by bleaching powder $(10 \mathrm{mg} / \mathrm{l}$ chlorine) and then basal fertilization ( 3 tonn cow dung and $30 \mathrm{~kg}$ single super phosphate / ha) were carried out before stocking of fingerlings (Jena et al., 2005). Three different species combinations were taken i.e. Control (T1) (Catla : Rohu :Mrigal) at the ratio of 40:30:30 @ 10000 no. /ha and culture for 10 months. In Recommended practice incorporation of Puntius sarana @ $10 \%$ or 1000 no./ha in the Major Carp system i.e. (Catla :Rohu :Mrigal: Puntius) at the ratio of 40:30:30:10 @ 10000 no. / ha and culture for 6 months (T2). Incorporation of Puntius sarana @ $20 \%$ or 2000 no./ha in the Major Carp system i.e. (Catla :Rohu :Mrigal) at the ratio of 40:30:30:20 @ 10000 no. / ha and culture for 6 months (T3). In farmers practice they usually stocked mixed seeds (35-40) $\mathrm{mm}$ size of Indian Major Carps and not adopting the scientific Pisciculture practices. In recommended practice the farmers were provided with Complete technical support of raising of the minor Carp Species i.e. Puntius sarana through proper post stocking management measures to utilize the total food space available in the pond environment. Health management aspects were assessed by periodic sampling. Fish yield was recorded after harvesting. About 2.5-3 meter water depth was maintained throughout the study period. Water samples were collected from the ponds at 15 -day intervals between 07:00 and 08:00 $\mathrm{h}$ and analyzed for important parameters were measured following standard methods (APHA, 2014). Then the data like fish weight (gm), fish yield (Quintal/hectar), Survivability percentage, average net return and B: C was recorded and analysed using statistical tools like Average mean value and percentage. From the results of the analysis it is found out that mean weight gain of Puntius sarana / Olive barb were higher in T3 compared to T1 and T2. Daily weight gain and net fish yield in T2 and T3 were also higher than T1. In the present study stocking of Puntius sarana \& IMC fingerlings of recommended size and density along with adopting the post stocking management schedules resulting the increase in Avg. weight of Olive barb upto $315 \mathrm{gm}$ where as the weight of IMC remains 420 gm during harvesting . Net profit of Rs. 1,67,363 was obtained from this technology with benefit: cost (B: C) ratio of 2.75 against Rs. 76,197 and 1.83 respectively from Control (T1) due to more fish growth \& production. Similarly $56.55 \%$ increase in fish yield was also observed in this technology $(26.3 \mathrm{q} / \mathrm{ha})$ against Control (16.8 q/ha). 


\section{Introduction}

Carp based aquaculture system is very common practice in India. Most of the farmers of India culture catla and rohu for their higher value in market, preference by consumer and fast growth rate. But for enhancing the yield \& income species diversification is one of the best option for incorporating other locally available fish species (Sinha et al., 2012) with Indian Major Carps (IMC) in a polyculture system (Nair and Salin, 2007). There are many minor carp species available in the natural water bodies of India having cultural potential and regional importance. (Das and Mishra, 2016). The olive barb, Puntius sarana is a medium sized carp species and found to be having moderate growth rate as compared to other major carps. The higher consumer preference, even at smaller size of 100-200 g, is resulting the species a suitable one for diversification (Gopakumar et al., 1999; Chakraborty et al., 2003) and also well known as short term income generating Enterprises through the use of seasonal ponds. Since the species possesses culture potential, its introduction into the Composite fish culture system would not only help in diversification of culture practices, but also can serve for its conservation.

The technique of induced breeding using synthetic inducing agents like Ovaprim and mass scale seed rearing of the species has already been standardized (CIFA, 2007) in water bodies. So in the present context it is very essential to know the compatible nature of this species with carps for optimum \& sustainable production from Composite fish culture system. Considering the availability of limited literature on grow-out farming of the species, and its compatibility with other species in particular, the present study was done to generate information, to create mass awareness among farmers \& for popularizing the species among them, besides satisfying to its conservation needs.

\section{Materials and Methods}

The experiment was conducted for Ten months from June, 2018 to March, 2019 in nine earthen ponds of 0.3 ha (3 no. ponds), 0.4 ha ( 3 no. ponds) $\& 0.5$ ha ( 3 no. ponds) of three different villages of Angul district. In the first phase Pre-stocking pond preparation methods are followed i.e. removal of predatory and weed fishes by bleaching powder (10 mg/l chlorine) and then basal fertilization (3 tonn cow dung and $30 \mathrm{~kg}$ single super phosphate / ha) were carried out before stocking of fingerlings (Jena et al., 2005). Three different species combinations were taken i.e. Control (T1) (Catla : Rohu :Mrigal) at the ratio of 40:30:30@10000 no. /ha and culture for 10 months. In Recommended practice incorporation of Puntius sarana@10\% or 1000 no./ha in the Major Carp system i.e. (Catla :Rohu :Mrigal: Puntius) at the ratio of 40:30:30:10@10000 no. / ha and culture for 6 months (T2). Incorporation of Puntius sarana@ $20 \%$ or 2000 no./ha in the Major Carp system i.e. (Catla :Rohu :Mrigal) at the ratio of 40:30:30:20@10000 no. / ha and culture for 6 months (T3). In farmers practice they usually stocked mixed seeds (35-40) $\mathrm{mm}$ size of Indian Major Carps and not adopting the scientific Pisciculture practices. In recommended practice the farmers were provided with Complete technical support of raising of the minor Carp Species i.e. Puntius sarana to utilize the total food space available in the pond environment. Fishes were fed with mixture of rice bran and groundnut oil cake in a 1:1 ratio (w/w) at $5 \%$ of biomass per day during first month, 3\% during second and third months, $2 \%$ in fourth to sixth month and $1.5 \%$ in rest of the culture period. The quantity of daily feed was calculated based on average fish growth recorded through monthly sampling. Daily ration was provided 
once daily at 07:00-08.00 h. Intermittent fertilization was carried out with fortnightly application of $500 \mathrm{~kg}$ cow dung, $10 \mathrm{~kg}$ urea and $15 \mathrm{~kg}$ single super phosphate (SSP) per hectare to maintain pond fertility in the subsequent period (Jena et al., 2005). Intermittent liming was also done at $100 \mathrm{~kg} /$ ha at 3-month intervals. Water samples were collected from the ponds at 15-day intervals between 07:00 and 08:00 $\mathrm{h}$ and analyzed for important parameters were measured following standard methods (APHA, 2014). Health management aspects were assessed by periodic sampling. Fish yield was recorded after harvesting. About 2.5-3 meter water depth was maintained throughout the study period. Then the data like fish weight (gm), fish yield (Quintal/hectar), average net return and $\mathrm{B}$ : $\mathrm{C}$ was recorded and analysed using statistical tools like Average mean value and percentage.

\section{Results and Discussion}

During the culture, the $\mathrm{pH}$ of water varied between 7.22-8.45 with no marked difference among the treatments (Table 1). Dissolved oxygen also did not show marked variation among treatments and remained between 4.11 to $4.18 \mathrm{mg} / \mathrm{l}$ in most part of the year. The other water parameters like total alkalinity, free carbon dioxide and hardness did not record any marked trend in the treatments during the culture(Table 1).. Total Ammonia Nitrogen contents in water varied insignificantly in treatments within a range of 0.31 to $0.36 \mathrm{mg} / \mathrm{l}$. Nitrite and Nitrate did not show any marked variation among the treatments. Most of the water quality parameters in the ponds during the culture were within suitable limit for carp culture (Das et al., 2004; Jena et al., 2002a, 2007a; Sahu et al., 2007; Tripathi et al., 2000). It might be due to management measures taken at regular interval of time i.e. liming, fertilization and water exchange. The higher
$\mathrm{pH}$ values during seventh and eighth month of culture (December - January) were might be due to the use of higher dose of lime as preventive for disease outbreak at the onset of winter. The average harvested body weight of IMC was similar in the three treatments (PN 0.05) (Table 3). Olive barb showed a significantly lower average body weight (ABW) as compared to IMC. Puntius sarana showed the highest survival of $64.6 \%$ among the treatments, while the same in IMC was the lowest $(44.21 \%)$ (Table 3). Such higher survivals of the species indicated its robustness, one of the important characters that favours its incorporation into the carp polyculture system. The result follows the trend found by (Das and Mishra, 2016) in earthen ponds at research stations and (Jena et $a l ., 2007$ ) that the relatively higher survival of silver barb indicates its better adaptability to the culture condition. The average weight gain of IMC was 412 and $420 \mathrm{~g}$ in T2 and T3 respectively. The average weight gain of Puntius sarana was $315 \mathrm{~g}$ in T3 in 5-6 months of culture. The results also falls in line with the study of (Haque et al., 1998) that a significantly higher $(\mathrm{P}<0.05)$ fish yield $(1793.65 \mathrm{Kg} / \mathrm{ha} / \mathrm{yr})$ was observed in the four species polyculture system containing Puntius gonionotus when the combined yield of all species was compared. Average gross production was calculated after final harvesting of the ponds and found to be 2520 and $2630 \mathrm{~kg}$ in T2 and T3 respectively. After sixth months of culture period the minor carps were harvested and left the major carps to grow for rest of the period. Farmers in this study perceived that incorporation of minor carps and harvesting after 5-6 months is profitable which supplements intermediary income during the crop cycle. This study is similar to the reports given by (Das, 2012). Inclusion of minor carps and barbs in culture system has been proven to be advantageous in terms of increasing biomass harvest from the pond. This not only reduces the capital 
investment in the system, but also part of the sale price can further be utilized towards feed cost during the subsequent culture of major carps (Das, 2015). In the present study the economic analysis was performed to find out the benefit cost ratio and the gross/net return (Table 4). Net profit of Rs. 1,67,363 was obtained from this technology with benefit: cost (B: C) ratio of 2.75 against Rs. 76,197 and 1.83 respectively from Control (T1) due to more fish growth \& production(Table 4).
Similarly $56.55 \%$ increase in fish yield was also observed in this technology (26.3 q/ha) against Control (16.8 q/ha) (Table 2). There are a number of studies related to incorporation of medium carps and barbs into the polyculture system, which indicate their production potential and profitability (Jena et al., 2007; Das and Mishra, 2016; Haque et al., 1998).

Table.1 Ranges of different physico-chemical parameters of water for the different treatment during the culture period

\begin{tabular}{|l|l|l|l|l|l|}
\hline Parameters & Treatments & & & Minimum & Maximum \\
\cline { 2 - 5 } & Control ( $\left.\mathbf{T}_{\mathbf{1}}\right)$ & $\mathbf{T}_{\mathbf{2}}$ & $\mathbf{T}_{\mathbf{3}}$ & & \\
\hline pH & $7.62 \pm 0.54$ & $7.73 \pm 0.63$ & $7.68 \pm 0.62$ & 7.22 & 8.45 \\
\hline $\begin{array}{l}\text { Dissolved Oxygen } \\
\text { (mg/l) }\end{array}$ & $4.15 \pm 0.036$ & $4.14 \pm 0.015$ & $4.15 \pm 0.02$ & 4.11 & 4.18 \\
\hline Free Carbon dioxide (mg/l) & $4.09 \pm 0.01$ & $4.09 \pm 0.02$ & $4.09 \pm 0.015$ & 4.07 & 4.12 \\
\hline Alkalinity (mg/l) & $40 \pm 1.0$ & $39.67 \pm 1.53$ & $41 \pm 1.0$ & 38 & 42 \\
\hline Hardness (mg/l) & $38.67 \pm 3.05$ & $39.67 \pm 1.53$ & $38.33 \pm 1.53$ & 36 & 42 \\
\hline Ammonia (mg/l) & $0.33 \pm 0.015$ & $0.32 \pm 0.015$ & $0.34 \pm 0.02$ & 0.31 & 0.36 \\
\hline Nitrite (mg/l) & $0.02 \pm 0.01$ & $0.01 \pm 0.005$ & $0.02 \pm 0.01$ & 0.01 & 0.03 \\
\hline Nitrate (mg/l) & $0.13 \pm 0.01$ & $0.14 \pm 0.01$ & $0.13 \pm 0.01$ & 0.12 & 0.15 \\
\hline Phosphate (mg/l) & $0.22 \pm 0.01$ & $0.22 \pm 0.015$ & $0.23 \pm 0.015$ & 0.21 & 0.24 \\
\hline
\end{tabular}

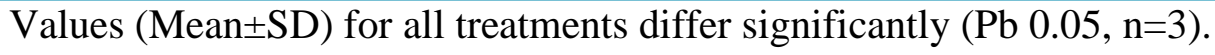

Table.2 Abstract of fish yield

\begin{tabular}{|c|c|c|c|c|c|c|c|}
\hline $\begin{array}{l}\text { Sl } \\
\text { No. }\end{array}$ & $\begin{array}{l}\text { Pond } \\
\text { area } \\
\text { (ha) }\end{array}$ & $\begin{array}{l}\text { Production } \\
\text { from check } \\
\text { pond (qtl.) }\end{array}$ & 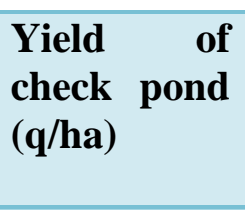 & $\begin{array}{l}\text { Production } \\
\text { from } \\
\text { Demonstrated } \\
\text { pond (qtl.) }\end{array}$ & $\begin{array}{l}\text { Yield of } \\
\text { Demonstrated } \\
\text { pond }(q / h a)\end{array}$ & $\begin{array}{l}\text { Production } \\
\text { from } \\
\text { Demonstrated } \\
\text { pond (qtl.) }\end{array}$ & $\begin{array}{l}\text { Yield of } \\
\text { Demonstrated } \\
\text { pond (q/ha) }\end{array}$ \\
\hline 1 & 0.3 & 5.16 & 17.2 & 6.84 & 22.8 & 6.99 & 23.3 \\
\hline 2 & 0.4 & 6.96 & 17.4 & 10.08 & 25.2 & 10.36 & 25.9 \\
\hline 3 & 0.5 & 7.9 & 15.8 & 13.8 & 27.6 & 14.85 & 29.7 \\
\hline & & & Avg. $=16.8$ & & Avg. $=25.2$ & & Avg. $=26.3$ \\
\hline
\end{tabular}


Table.3 Yield attributes \& growth analysis of Carp species (after 6 months of observation)

\begin{tabular}{|c|c|c|c|c|}
\hline Treatments & Species & $\begin{array}{l}\text { Stocking density } \\
\text { (No./ha) }\end{array}$ & $\begin{array}{l}\text { Average Body } \\
\text { Weight (gm) }\end{array}$ & $\begin{array}{l}\text { Survivability } \\
(\%)\end{array}$ \\
\hline Control (T1) & IMC (Catla, Rohu \& Mrigal) & 10000 (IMC) & 380 (IMC) & 44.21 \\
\hline $\mathbf{T} 2$ & $\begin{array}{l}\text { IMC (Catla, Rohu, Mrigal) \& } \\
\text { Puntius sarana }\end{array}$ & $\begin{array}{l}10000 \text { (IMC) }+1000 \\
(\text { Puntius sarana) }\end{array}$ & $\begin{array}{l}412 \text { (IMC) } \\
305 \quad \text { (Puntius } \\
\text { sarana) }\end{array}$ & $\begin{array}{l}56.43(\mathrm{IMC}) \\
64 \quad \text { (Puntius } \\
\text { sarana) }\end{array}$ \\
\hline T3 & $\begin{array}{l}\text { IMC (Catla, Rohu, Mrigal) \& } \\
\text { Puntius sarana }\end{array}$ & $\begin{array}{l}10000(\mathrm{IMC})+2000 \\
((\text { Puntius sarana })\end{array}$ & $\begin{array}{l}420 \text { (IMC) } \\
315 \quad \text { (Puntius } \\
\text { sarana) }\end{array}$ & $\begin{array}{l}52.92 \text { (IMC) } \\
64.6 \quad \text { (Puntius } \\
\text { sarana) }\end{array}$ \\
\hline
\end{tabular}

Table.4 Abstract of economic parameters

\begin{tabular}{|l|l|l|l|l|l|l|}
\hline $\begin{array}{l}\text { Technology } \\
\text { option }\end{array}$ & $\begin{array}{l}\text { No. of } \\
\text { trials }\end{array}$ & $\begin{array}{l}\text { Yield } \\
\text { (q/ha) }\end{array}$ & $\begin{array}{l}\text { Cost of } \\
\text { cultivation } \\
\text { (Rs./ha) }\end{array}$ & $\begin{array}{l}\text { Gross return } \\
\text { (Rs/ha) }\end{array}$ & $\begin{array}{l}\text { Net return } \\
\text { (Rs./ha) }\end{array}$ & BC ratio \\
\hline T1 & 03 & 16.8 & 91,803 & $1,68,000$ & 76,197 & 1.83 \\
T2 & & 25.2 & 93,333 & $2,52,000$ & $1,58,667$ & 2.7 \\
T3 & & 26.3 & 95,636 & $2,63,000$ & $1,67,363$ & 2.75 \\
\hline
\end{tabular}

It is concluded, in view of the recent emphasis on species diversification in freshwater aquaculture system, the present study showed the potentiality of olive barb as an important candidate for incorporation in Composite pisciculture system. Incorporation of Puntius sarana@20\% or 2000 no./ha in the Major Carp system i.e. (Catla :Rohu :Mrigal) @ 10000 no. /ha and culture for 5-6 months increases yield $56 \%$ over farmers practice leading to maximization of profit. However, further study may be carried out to assess the optimum level of its incorporation in grow out Composite fish culture system.

\section{References}

1. Ananth PN, Sahoo PR, Dash AK, Pati BK, Jayasankar P, Singh SRK. 2014: A Study on Community Based Aquaculture Promoted by KVK-Khordha, Odisha, India. Current World Environment; 9(3):947-951

2. APHA. Standard methods for the examination of water and wastewater (20th ed.)2014. Washington, DC: Author/American Water Works Association/Water Environment Federation.

3. Chakraborty, B.K., Miah, M.I., Mirza, M.J.A., Habib, M.A.B., 2003. Rearing and nursing of local Sarpunti, Puntius sarana, (Hamilton) at different stocking densities. Pakistan J. Biol. Sci. 6 (9), 797-800.

4. CIFA, 2007. Annual Report 2006-07. Central Institute of Freshwater Aquaculture, Bhubaneswar, India.

5. Das PC, Mishra B. 2016: Multi-species farming of major and minor carps for enhancing fish production in freshwater aquaculture. Indian J. Fish.; 63(2):55-61.

6. Das PC. 2012: Minor carps and barbs in aquaculture: Importance and technology for their seed production and grow-out culture. In: K. Das Mahapatra, P. Routray, N. K. Barik, P. Jayasankar (eds). Quality fish seed production through brood fish management, ICARCentral Institute for 
Freshwater Aquaculture, Bhubaneswar, Odisha, India, 128-137

7. Das PC. 2015: Multispecies farming of minor carps and barbs along with Indian Major Carps to increase pond productivity. In Das, P.C., Sahoo, S.K \& Sanga, L (Eds) E-book Summer School Aquaculture Diversification towards boosting pond productivity and farm income, Indian Council of Agricultural Research, New Delhi.

8. Gopakumar, K., Ayyappan, S., Jena, J.K., Sahoo, S.K., Sarkar, S.K., Satapathy, B.B., Nayak, P.K., 1999. National Freshwater Aquaculture Development Plan. Central Institute of Freshwater Aquaculture, Bhubaneswar, India, p. 75.

9. Hand book on fisheries statistics.2014: Department of Animal husbandry, Dairying and Fisheries, Ministry of Agriculture, Government of India, New Delhi, 166.

10. Haque SM, Wahab MA, Wahid MI, Haq MS.1998: Impacts of Thai silver barb (Puntius gonionotus Bleeker) inclusion in the polyculture of carps. Bangladesh $\mathrm{J}$. Fish. Res; 2(1):15-22.

11. Jena JK, Ayyappan S, Aravindakshan PK. 2002: Comparative evaluation of production performance in varied cropping patterns of carp polyculture systems. Aquaculture; 207:49-64.

12. Jena JK, Das PC, Das R, Mondal S. 2007: Performance of olive barb, Puntius sarana (Hamilton) in fingerling rearing with rohu,
Labeo rohita (Hamilton) and mrigal, Cirrhinus mrigala (Hamilton), Aquaculture ; 265:305-308.

13. Mondal SC, Barman D, Das P.2011: Modern approach of composite fish culture-the examples of Andhra Pradesh (India) to emulate, World Aquaculture, 4446

14. Nair MC, Salin KR. Carp culture in India: 2007. Practices, Emerging Trends. Global Aquaculture Advocate, 54-16

15. Panda S. 2016: Composite fish culture for gainful employment. International Journal of Bioassyas; 5(6):4593-4596.

16. Radheyshyam.2010: Carp seed production at rural front in Orissa, India. Aquaculture Asia; 25(2):20-24.

17. Sahu, P.K., Jena, J.K., Das, P.C., Mondal, S., Das, R., 2007. Production performance of Labeo calbasu (Hamilton) in polyculture with three Indian major carps Catla catla (Hamilton), Labeo rohita (Hamilton) and Cirrhinus mrigala (Hamilton) with provision of fertilizers, feed and periphytic substrate as varied inputs.

18. Sinha A, Datta S, Mahapatra BK.2012: Diversification of Aquaculture, Narendra publication House,. New Delhi

19. Tripathi SD, Aravindakshan PK, Ayyappan S, Jena JK, Muduli HK, Chandra S et al., 2000: New dimensions in intensive carp polyculture in India. J. Aquac. Tropics.; 15(2):119-128.

\section{How to cite this article:}

Rashmi Prabha Mishra, Navin Kumar, Sudhir Kumar Das, Jyotiprabha Mishra and Nihar Ranjan Sarangi. 2020. Growth Performance, Yield \& Return of Puntius sarana (Hamilton, 1822) from Dry Seasonal Water Bodies of Angul District, Odisha, India. Int.J.Curr.Microbiol.App.Sci. 9(03): 765-770. doi: https://doi.org/10.20546/ijcmas.2020.903.091 